\title{
Buford Norman, Quinault, librettiste de Lully. Le poète des Grâces
}

Daniela Dalla Valle

\section{(2) OpenEdition}

1 Journals

\section{Edizione digitale}

URL: http://journals.openedition.org/studifrancesi/6618

DOI: $10.4000 /$ studifrancesi.6618

ISSN: 2421-5856

\section{Editore}

Rosenberg \& Sellier

\section{Edizione cartacea}

Data di pubblicazione: 1 septembre 2010

Paginazione: 360

ISSN: 0039-2944

\section{Notizia bibliografica digitale}

Daniela Dalla Valle, «Buford Norman, Quinault, librettiste de Lully. Le poète des Grâces», Studi Francesi

[Online], 161 (LIV | II) | 2010, online dal 30 novembre 2015, consultato il 11 janvier 2021. URL: http:// journals.openedition.org/studifrancesi/6618; DOI: https://doi.org/10.4000/studifrancesi.6618

Questo documento è stato generato automaticamente il 11 janvier 2021.

\section{(c) (i) (9)}

Studi Francesi è distribuita con Licenza Creative Commons Attribuzione - Non commerciale - Non opere derivate 4.0 Internazionale. 


\title{
Buford Norman, Quinault, librettiste de Lully. Le poète des Grâces
}

\author{
Daniela Dalla Valle
}

\section{NOTIZIA}

BUFORD NORMAN, Quinault, librettiste de Lully. Le poète des Grâces, Wavre, Mardaga (Centre de Musique Baroque de Versailles), 2009, pp. 383.

1 Buford Norman è noto come uno dei più illustri specialisti di Quinault, su cui pubblicò nel 2001 il volume Touched by the Graces (Summa Publications), che ora è tradotto $\mathrm{e}$ pubblicato in francese. Non possiamo che rallegrarci per questa nuova pubblicazione del volume (oltre che tradotto, rivisto e aumentato), perché essa contribuisce a diffondere la conoscenza di una parte non sufficientemente nota della seconda parte del Seicento, dominata appunto da Quinault che - proprio come librettista di Lulli ottenne un successo straordinario, caratterizzando la cultura classica.

2 Nell'introduzione il volume presenta la tragedia lirica e la colloca all'interno del teatro classico; poi dedica il primo capitolo ai Prologhi delle opere di Quinault e Lulli, mentre i capitoli successivi-dal 2 al 12 -sono dedicati alle undici opere uscite dalla loro collaborazione, inizialmente ispirate al mondo classico - nove tragédies en musique, da Cadmus et Hermione fino a Phaéton-, poi tre tragédies en musique, ispirate a poemi o a romanzi di cavalleria - Amadis, Roland e Armide.

Dopo la conclusione, segue una serie di Annexes (i libretti di Quinault rimessi in musica e modificati, una nota biografica su Quinault, l'elenco delle sue opere); infine una ricca bibliografia e una serie di indici. 